\title{
Improve The Logical Reasoning Ability of Primary School Students by Using Video Learning Assistant Teaching
}

\author{
Zhouli Huang ${ }^{1}$, Ying Zhou ${ }^{2}$, Tommy Tanu Wijaya ${ }^{3}, \mathrm{Ke} \mathrm{Yan}^{4}$ \\ 1,2 Department of Mathematics and Statistics, Guangxi Normal University, Guilin, China \\ ${ }^{3}$ School of Mathematical Sciences, Beijing Normal University, Beijing, China \\ ${ }^{4}$ School of mathematics and physics, Yongzhou Normal College, Yongzhou, China \\ Zhouying66@mailbox.gxnu.edu.cn
}

\begin{abstract}
Under the current situation of epidemic prevention and control, to ensure the continuous progress of student learning, Chinese Ministry of Education put forward the initiative of "suspension of classes without suspension of school". Primary and secondary schools have adopted online learning at home for students to "open schools in the cloud. There is a big difference between online learning and classroom learning. In this process, problems such as increased teaching burden of teachers, lack of interaction between teachers and students, and students' lack of active learning are also exposed. Video learning are a new type of teaching resource. It can improve the efficiency of primary school mathematics teaching by using video learning reasonably. Based on the above analysis, the purpose of this research is to investigate the development of primary school students' logical reasoning ability through the use of video leanings for auxiliary teaching. The research method adopts the experimental method and is divided into the experimental class and control class. The subjects of the study were 72 students from a primary school in Indonesia. Experimental results show that video learning for auxiliary teaching can effectively develop students' logical reasoning ability.
\end{abstract}

Keywords: logical reasoning ability, video learning, mathematics teaching

\begin{abstract}
Abstrak
Di bawah situasi pencegahan dan pengendalian epidemi saat ini, untuk memastikan kemajuan pembelajaran siswa yang berkelanjutan, Kementerian Pendidikan Tiongkok mengajukan inisiatif "penangguhan kelas tanpa penangguhan sekolah". Sekolah dasar dan menengah telah mengadopsi pembelajaran online di rumah bagi siswa untuk "membuka sekolah di awan. Ada perbedaan besar antara pembelajaran online dan pembelajaran di kelas. Dalam proses ini, masalah seperti beban mengajar guru yang meningkat, kurangnya interaksi antara guru dan siswa, dan kurangnya pembelajaran aktif siswa juga terungkap. Kelas mikro adalah jenis sumber pengajaran baru. Mengintegrasikan sumber kelas mikro secara efektif ke dalam pengajaran matematika sekolah dasar dapat meningkatkan efisiensi pengajaran matematika. Berdasarkan analisis di atas, tujuannya penelitian ini adalah untuk mengetahui perkembangan kemampuan penalaran logis siswa sekolah dasar melalui penggunaan kelas mikro untuk pembelajaran bantu.Metode penelitian ini mengadopsi metode eksperimen dan dibagi menjadi kelas eksperimen dan kelas kontrol.Subjek penelitian sebanyak 72 siswa dari sebuah sekolah dasar di Indonesia.Hasil eksperimen menunjukkan bahwa kelas mikro untuk auksi pengajaran pembohong dapat secara efektif mengembangkan kemampuan penalaran logis siswa.
\end{abstract}

Kata kunci: kemampuan penalaran, Video Learning, pelajaran matematika

Copyright (c) 2019 Zhouli Huang, Ying Zhou, Tommy Tanu Wijaya, Ke Yan

Corresponding author: Zhouli Huang

Email Address: Zhouying66@mailbox.gxnu.edu.cn (Guangxi Normal University, Guilin, China)

Received 10 August 2021, Accepted 27 August 2021, Published 27 August 2021

\section{INTRODUCTION}

Mathematics is the science of quantitative relations and spatial forms (Setyono \& Cahyo, 2017; Tambychik \& Meerah, 2010). The development of mathematics depends on logical reasoning, which leads to mathematical conclusions, namely mathematical propositions (Ayuningtyas, Mardiyana, \& Pramudya, 2019). Inference refers to the thinking process from the judgment of propositions to the judgment of propositions, in which propositions are statements that can be used to determine whether 
they are true or false (Wang, 2019). The so-called logical reasoning refers to the thinking process of obtaining or verifying propositions from some premises or facts according to specific rules (Guthrey, 2015). The rules mentioned here refer to the transitivity of the reasoning process. Logical reasoning ability plays an important role in people's learning and life (Ayuningtyas et al., 2019; Siti Chotimah, Bernard, \& Wulandari, 2018). It is the ability to use logical reasoning activities to think and is an important part of the thinking development of primary school students (Vicente, Sánchez, \& Verschaffel, 2020).

Due to the outbreak, students are unable to attend classes at school and can only study online (Bacher-Hicks, Goodman, \& Mulhern, 2021; Dong, Cao, \& Li, 2020; Wijaya, 2021). Online learning puts teachers and students in the "cloud", unable to communicate face to face. For students with weak self-restraint ability, lack of self-discipline, and weak foundation, this way of learning is easy to make their learning effect decline. Video learning can be used to supplement the classroom (Putra, Witri, \& Sari, 2020; Wijaya, Ying, \& Suan, 2020). Its functions are mainly shown as follows (Wijaya, Li, Hermita, Putra, \& Alim, 2021): 1. It is suitable for teachers to learn from when preparing lessons;2. Suitable for students with learning difficulties; 3 , suitable for parents to tutor children; 4 , suitable for students to review after class;5. Making up lessons and learning in different places for students who are absent from classes; 6 . It is suitable for the self-study of holiday students. As students are different, it is difficult for students of different levels to consider the differences in unified teaching. How to coordinate this contradiction, video learning is conducive to implementing hierarchical teaching. Video Learning resources can also be repeatedly used. Time and place will not be limited. There is a lot of freedom, independent space (Weinberg \& Thomas, 2018). The characteristics of mathematics Video learning: teaching video is short and pithy; Clear teaching objectives; Clear teaching information, quick review and detection (Giannakos, Krogstie, \& Aalberg, 2016; Wijaya, Hidayat, \& Zhou, 2020).

In order to improve students' logical reasoning ability, video learning is now used as an auxiliary tool for online mathematics teaching (Wijaya, 2021). Teachers use video learning to assist teaching. According to students' actual cognitive level and textbook content, they reorganize mathematical knowledge and make students feel the rich and colorful application of mathematical knowledge and build classroom effectiveness. In teaching mathematical problem solving, it is often impossible to start from the topic, find the way to solve the problem, and realize the connection between conditions and problems. Video learning is also an extension of the classroom content. For example, after the "chicken and rabbit cage together" teaching, the teacher asks the students: can you think of other solutions? We can't spend too much time summarizing these methods in the class, but video learning can help us. We can use mini - lessons to introduce several other typical methods and reveal how they are related and where they are used.

According to the above information, this study takes video learning as an auxiliary tool for primary school students to learn mathematics online. The purpose of this study is to explore the use of additional tools for online teaching and analyze the logical reasoning ability of primary school students 
Improve The Logical Reasoning Ability of Primary School Students by Using Video Learning Assistant Teaching, Zhouli Huang, Ying Zhou, Tommy Tanu Wijaya, Ke Yan

before and after learning "chicken and rabbit cage together (the first period)".

\section{METHOD}

Online teaching method and video learning assisted teaching method were used to conduct mathematics teaching respectively to analyze whether the logic understanding ability of primary school students has been developed. The method used in this study is the experimental method. The research objects are two classes. One is the control class, and the other is the experimental class. The control group carries out mathematics teaching by online teaching, while the experimental group uses online teaching and video learning assistance. The study be pre-tested and post-tested (S. Chotimah, Wijaya, Aprianti, Akbar, \& Bernard, 2020).

Table 1. Research project

\begin{tabular}{|l|l|l|l|}
\hline A-CLASS & pre-test & video learning & post-test \\
\hline B-CLASS & pre-test & & post-test \\
\hline
\end{tabular}

Note: A-CLASS experimental class; B-CLASS control class; pre-test logical reasoning ability pre-test; post-test logical reasoning ability post-test; video learning uses video learning to assist teaching and learning "chicken and rabbit in the same cage (first lesson)"

The students' logical reasoning ability data will be extracted from the pre-test and post-test results. Use Microsoft Excel to process the data of the two samples separately. The data results will be processed with SPSS 21.0 for windows, the steps are: check the normality of the sample data; Mann-Whitney U test.

\section{RESULTS AND DISCUSSIONS}

\section{Result analysis}

According to the obtained pre-test data, a data file is established, and the following results are obtained:

Table 2. Normality pre-test result

\begin{tabular}{|c|r|r|r|r|r|r|r|}
\hline \multirow{2}{*}{ Student } & \multicolumn{2}{|c|}{ Kolmogorov-Smirnov $^{\text {a }}$} & \multicolumn{3}{c|}{ Shapiro-Wilk } \\
\cline { 3 - 9 } & Statistic & df & \multicolumn{1}{c|}{ Sig. } & Statistic & df & \multicolumn{1}{c|}{ Sig. } \\
\hline \multirow{2}{*}{ ability } & control & .321 & 36 & .000 & .499 & 36 & .000 \\
\cline { 2 - 9 } & experiment & .190 & 36 & .002 & .900 & 36 & .003 \\
\hline
\end{tabular}

From Table 2 that the significance probability of the control group Sig. $=0.000$, and the significance probability of the experimental group Sig. $=0.002$. The control group's significance probability and the experimental group are less than 0.05 , and the hypothesis $\mathrm{H} 0$ is rejected. In other words, the distribution of pre-test samples is not uniform. Therefore, the independent sample Mann-Whitney $U$ test is performed next. 
Table 3. Average pre-test result on students' logical reasoning ability

\begin{tabular}{|c|c|}
\hline & logical reasoning ability \\
\hline Mann-Whitney U & 565.500 \\
\hline Wilcoxon W & 1231.500 \\
\hline Z & -.946 \\
\hline Asymp. Sig. (2-tailed) & .344 \\
\hline
\end{tabular}

From Table 3 that the significance level value is 0.344 . 0.344>0.05. Therefore, the distribution of students' preliminary reasoning ability is the same in the student category. Therefore, this research's experimental courses will be conducted under the same conditions, and effective post-test experimental results can be obtained.

According to the obtained post-test data, a data file is established, and the following results are obtained:

Table 4. Normality post-test result

\begin{tabular}{|c|c|c|c|c|c|c|c|}
\hline \multicolumn{2}{|c|}{ Student } & \multicolumn{3}{c|}{ Kolmogorov-Smirnov $^{\mathrm{a}}$} & \multicolumn{3}{c|}{ Shapiro-Wilk } \\
\cline { 3 - 8 } & Statistic & df & Sig. & Statistic & df & Sig. \\
\hline \multirow{2}{*}{ ability } & control & .187 & 36 & .003 & .714 & 36 & .000 \\
\cline { 2 - 8 } & experiment & .188 & 36 & .002 & .806 & 36 & .000 \\
\hline
\end{tabular}

From Table 4 that the significance probability of the control group Sig. $=0.003$, and the significance probability of the experimental group Sig. $=0.002$. The control group's significance probability and the experimental group are less than 0.05 , and the hypothesis $\mathrm{H} 0$ is rejected. In other words, the distribution of pre-test samples is not uniform. Therefore, the independent sample Mann-Whitney $U$ test is performed next.

Table 5. The average post-test result on students' logical reasoning ability

\begin{tabular}{|l|r|}
\hline & \multicolumn{1}{|c|}{ logical reasoning ability } \\
\hline Mann-Whitney U & 391.500 \\
\hline Wilcoxon W & 1057.500 \\
\hline$Z$ & -2.897 \\
\hline Asymp. Sig. (2-tailed) & .004 \\
\hline
\end{tabular}

It is easy to know from Table 5 that the significance level value is $0.004 .0 .004<0.05$. Therefore, reject H0. In other words, when using video learning to assist online mathematics teaching, students' logical reasoning ability is better than a single online mathematics teaching.

\section{Discussion}

Researchers use video learning to review students' online teaching of "chicken and rabbit together in a cage (the first class)". In this video learning, there are five parts: the introduction of the scene to stimulate interest; Return to the classics, think about the problem; Try to solve, analyze the solution; Variable experience, consolidation, and application; Problem solving, class summary.

Part 1: Set the situation and arouse interest. As shown in Figure 1, this activity tells a question that a student met in a test: now there are a chicken and a rabbit in the same cage. There are thirty-five heads counted from the top and ninety-four legs counted from the bottom. How many chickens and rabbits 
are there each? The video learning vividly tells the interesting story of the student's solution to the topic, which can improve the students' interest in learning the content of this section and trigger the students' thinking and try to solve this topic.

\begin{tabular}{|c|c|}
\hline $\begin{array}{l}\text { 一、设置情景, 激发兴趣 } \\
\text { 今有雉兔同笼，上有三十五头， } \\
\text { 下有九十四足，问雉兔各几何? }\end{array}$ & $\begin{array}{l}\text { Step 1: Set the situation, arouse interest } \\
\text { Now, rabbits and chickens in the same cage, } \\
\text { form the top of the number of } 35 \text { heads, } \\
\text { from the bottom of the number of ninety- } \\
\text { four feet, how many rabbits and chickens } \\
\text { each have? }\end{array}$ \\
\hline
\end{tabular}

Figure 1. Set The Situation and Arouse Interest

Part 2: return to the classics, think about the problem. As shown in Figure 2, "chicken and rabbit in a cage together" is one of the three ancient mathematics interesting problems widely spread among Chinese people. By learning "chicken and rabbit together in a cage", students can feel the rich mathematical culture and cultivate mathematical thinking. In solving problems, students can accumulate and master mathematical knowledge and understand different problem-solving methods. In reasoning, guide the students to start with simple problems and solve mathematical problems from easy to difficult.

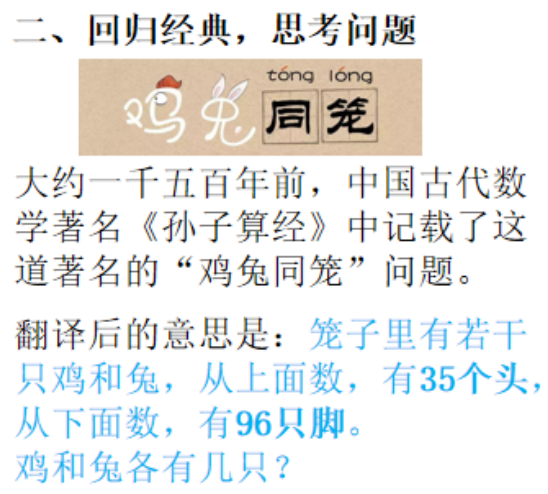

二、回归经典，思考问题

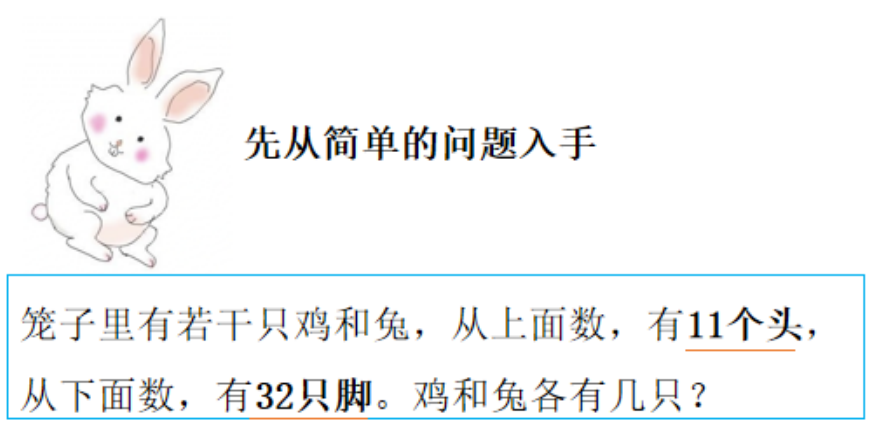

Step 2: Return to the classics, think about the problem rabbits and chickens in the same cage About 1,500 years ago, the famous problem of a chicken and a rabbit in a cage was recorded in the famous ancient Chinese mathematical book Sun Zi Suan Jing.

There are several chickens and rabbits in the cage, 35 heads counted from the top, 96 feet counted from the bottom. How many chickens and rabbits are there each?

Figure 2. Return to the Classics, Think about The Problem

Part 3: try to solve, analyze the solution. Guide students according to the known conditions, the 
unknown, to solve the problem. This section shows three ways to solve this problem: the enumeration method, the sham method, and the formulation of equations. Guiding students to explore is helpful to cultivate students' rigorous thinking quality and rational spirit of being brave to explore. The infiltration of enumeration, hypothesis, reasoning, model, and other mathematical thinking methods will constantly improve students' logical reasoning ability.

As shown in Figure 3, analyze the reasoning process of the list method. The enumeration method is helpful for students to understand and can effectively exercise students' ability of estimation and reasoning. Guide the students to guess the results of the list. The train of thought will be clearer. By observing the table, students can find a specific rule: for every additional chicken and less rabbit, the total number of legs decreases by two. Then they can apply the rule to solve the problem. List all the possibilities in order to write down all possible answers without repetition or omission.

\begin{tabular}{|c|c|c|c|c|c|}
\hline \multirow{2}{*}{\multicolumn{4}{|c|}{ 三、尝试解答，分析解法 }} & & \\
\hline & & & & & \\
\hline \multicolumn{3}{|c|}{$\begin{array}{l}\text { 笼子里有若干只鸡和兔, 从上面数, 有 } 11 \text { 个头, } \\
\text { 从下面数, 有 } 32 \text { 只脚。鸡和兔各有几只? }\end{array}$} & & & \\
\hline 鸡 (只) & 兔（只） & 总脚数 (只) & & Rabbit & number of feet \\
\hline 0 & 11 & 44 & & 11 & 44 \\
\hline 1 & 10 & 42 & & 10 & 42 \\
\hline 2 & 9 & 40 & & 9 & 40 \\
\hline 3 & 8 & 38 & & 8 & 38 \\
\hline 4 & 7 & 36 & & 7 & 36 \\
\hline 5 & 6 & 34 & & 6 & 34 \\
\hline 6 & 5 & 32 & & 5 & 32 \\
\hline$\cdots$ & $\cdots$ & $\cdots$ & & ... & $\cdots$ \\
\hline 11 & 0 & 22 & & $i_{0}$ & 22 \\
\hline \multirow{2}{*}{\multicolumn{4}{|c|}{ 答: 有6只鸡, 5只兔。 }} & \multicolumn{2}{|c|}{ So, there are six chickens and five rabbits. } \\
\hline & & & & \multicolumn{2}{|c|}{$\begin{array}{l}\text { For every one more chicken and one less rabbit, } \\
\text { the total number of legs decreases by two. }\end{array}$} \\
\hline
\end{tabular}

Figure 3. Try To Solve, Analyze the Solution

As shown in Figure 4, analyze the reasoning process of the dummy. First, assume a situation through deduction, verification to solve the problem. Learning to use false ways can make the problem simple, help train students' problem-solving skills, and develop students' logical reasoning ability. Assuming all chickens (or rabbits), the number of rabbits (or chickens) can be calculated by the difference between the number of legs obtained from the hypothesis and the actual number of legs. For example, if the cage is full of chickens, it can be expressed by the formula: number of rabbits = (total number of feet - total number of heads $\times 2) \div 2$, number of chickens $=$ total number of heads - number of rabbits.

First with the aid of intuition, guide the students to explore by drawing and list methods, and gradually to the solution of the image and abstract summary. By introducing the enumeration method and the false method and revealing the use of these two methods, students can find the limitations of 
these two methods, and it will be more difficult to solve the problems with large data.

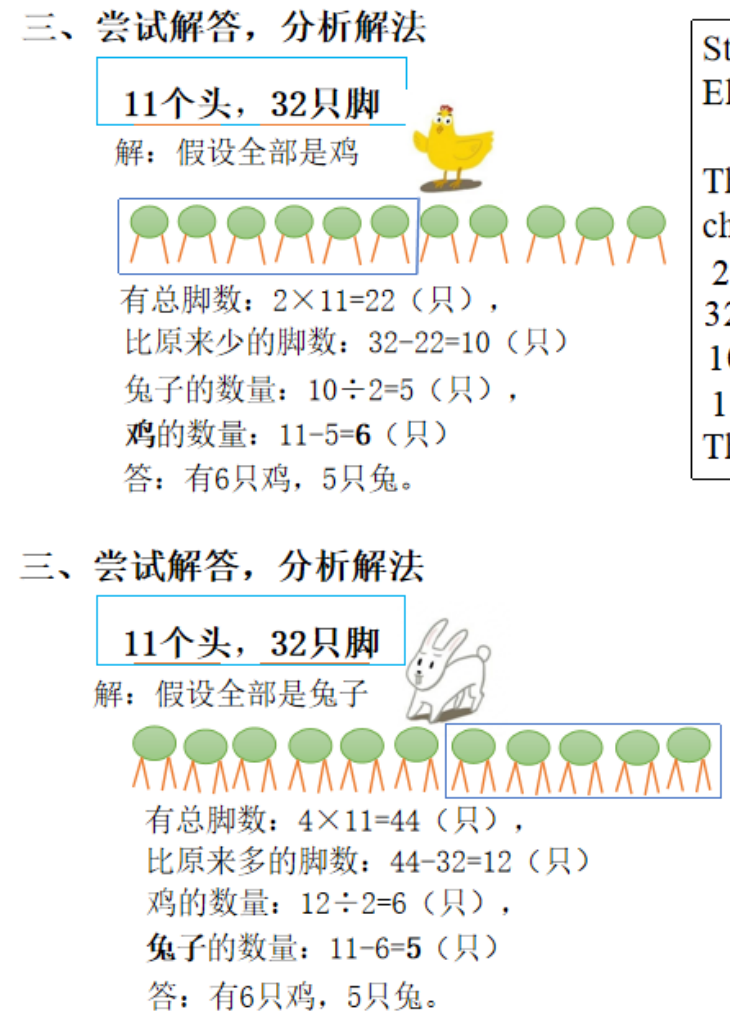

Step 3: try to solve, analyze the solution Eleven heads, 32 feet.

The first way: Assuming that the cage is full of chickens.

$2 \times 11=22$. So, the number of feet is 22 . $32-22=10$. There are 10 fewer feet than before. $10 \div 2=5$. So, the number of rabbits is 5 . $11-5=6$. So, the number of chickens is 6 . There are six chickens and five rabbits.

Step 3: try to solve, analyze the solution Eleven heads, 32 feet.

The second way: Assuming that the cage is full of rabbits.

$4 \times 11=44$. So, the number of feet is 44 . $44-32=12$. Twelve more feet than before. $12 \div 2=6$. So, the number of chickens is 6 . $11-6=5$. So, the number of rabbits is 5 . There are six chickens and five rabbits.

Figure 4. Analyze the Reasoning Process of The Dummy

As shown in Figure 5, analyze the reasoning process of setting up the equations. Guiding students to think about problems from different angles is helpful to develop students' divergent thinking abilities. In solving the problem, the ideas and methods are revealed step by step, and the general solving steps are summarized, which can promote the development of students' logical reasoning ability and abstract thinking. In this process, students can feel the rigor of mathematics and seek general methods to solve problems by observing, analyzing, exploring and summarizing the general rules of such problems. Such ideas and methods can develop students' thinking and help students transfer it to their future study and life.

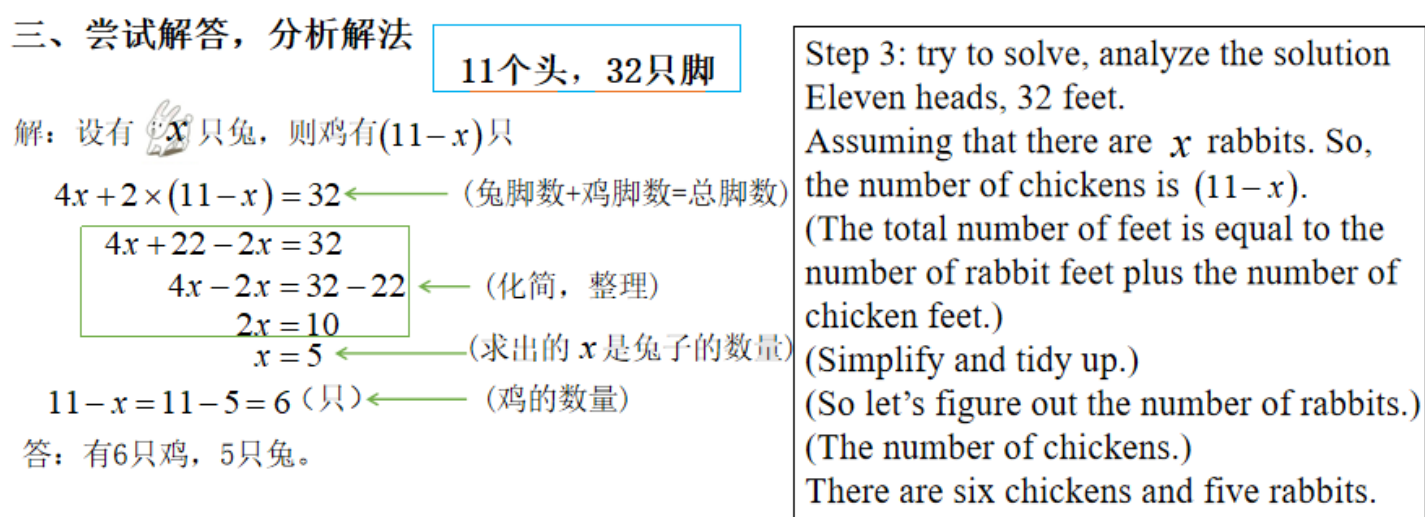

Figure 5. Analyze The Reasoning Process of Setting Up the Equations 
Part 4: Variable experience, consolidation, and application. As shown in Figure 6, students are guided to imitate and learn to solve such word problems through teacher's explanation. It can promote students' abstract thinking ability and help students form the habit of standard writing. At the same time, make equations to solve problems, the scope of application is larger. In learning mathematical knowledge and using mathematical knowledge to solve problems, students can form a practical and realistic, rigorous, and serious scientific spirit and the good quality of innovation, which is helpful to improve students' logical reasoning ability.

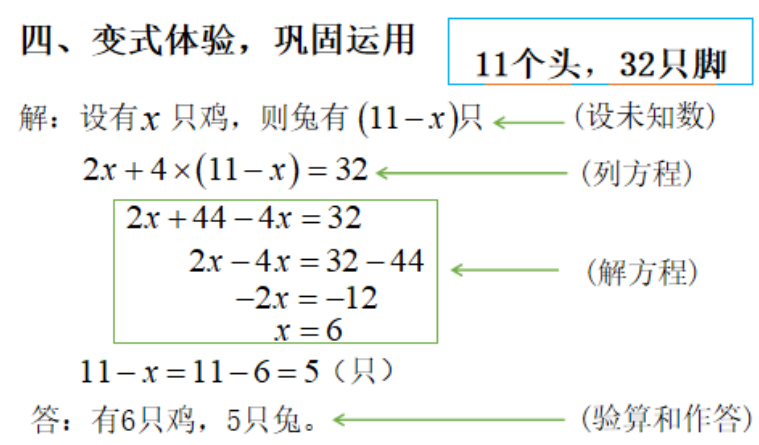

Step 4: Variable experience,
consolidated application
Eleven heads, 32 feet.
(Let's set the unknowns.)Assuming
that there are $x$ chickens.
So, the number of rabbits is $(11-x)$.
(Equation.)
(To solve the equation.)
(Check the calculation and answer the
questions.)
There are six chickens and five rabbits.

Figure 6. Variable Experience, Consolidation and Application

Part 5: problem-solving, class summary. As shown in Figure 7, students analyze their own ideas and apply mathematical knowledge to solve problems based on understanding. Guiding students to choose appropriate problem-solving methods to simplify complex problems and find correct problemsolving ideas can help students acquire problem-solving skills and cultivate their logical reasoning ability.

\section{五、问题解决, 课堂总结 \\ 笼子里有若干只鸡和兔, 从上面数, \\ 有 35 个头, 从下面数, 有 96 只脚。 \\ 鸡和兔各有几只? \\ 1、假设笼子里全是鸡, 需要加上多少只脚呢? \\ 兔子的数量是多少? \\ 2、假设笼子里全是兔子, 需要减去多少只脚呢? 鸡的数量是多少? \\ 3、你能尝试分别设鸡和兔子为 $x$ 只, 通过解方 程来解决问题吗?}

Step 5: Problem solving, class summary
There are several chickens and rabbits in the
cage, 35 heads counted from the top, 96 feet
counted from the bottom. How many
chickens and rabbits are there each?
1.If the cage is full of chickens, how many
feet do we need to add? What is the number
of rabbits?
2.If the cage is full of rabbits, how many feet
do I have to subtract? What's the number of
chickens?
3.Can you try to solve the problem by solving
the equation of chickens and rabbits
respectively?

Figure 7. Problem Solving, Class Summary

In the review process, there is less time, more content, higher requirements for a series of problems, and different students to master the content of this section is not the same. Using online teaching assisted by video learning, students can review selectively according to their actual situation, 
watch the doubtful knowledge points repeatedly, gradually understand the logical thinking contained in the topic, and deeply experience the reasoning process.

\section{CONCLUSIONS}

Through the analysis and discussion of the research results, it can be concluded that online mathematics teaching assisted by video learning is better than that of single online teaching, and students' logical reasoning ability is improved. Therefore, online mathematics teaching under the influence of the epidemic can improve students' logical reasoning ability, and video learning assisted teaching is better than single online mathematics teaching. However, researchers have also realized the shortcomings of this experiment. In online teaching assisted by Video learning, teachers and students cannot communicate face to face, which is a problem worth thinking. This study is inadequate in terms of research objects and fails to cover all primary school students in Indonesia. It can be improved in the future. Of course, under the impetus of The Times, online teaching assisted by video learning also needs constant optimization.

\section{ACKNOWLEDGEMENTS}

First of all, I would like to thank my tutor, Professor Zhou Ying. Teacher Zhou's patient instruction made my direction more clear. Secondly, I would like to thank my brothers and sisters, and friends. Thank you for explaining my doubts and encouraging me in my life and study. Finally, I would like to thank the editor and reviewers for taking time out of their busy schedule to read my paper. Thank you.

\section{REFERENCE}

Ayuningtyas, W., Mardiyana, \& Pramudya, I. (2019). Analysis of student's geometry reasoning ability at senior high school. Journal of Physics: Conference Series, 1188(1). https://doi.org/10.1088/1742-6596/1188/1/012016

Bacher-Hicks, A., Goodman, J., \& Mulhern, C. (2021). Inequality in household adaptation to schooling shocks: Covid-induced online learning engagement in real time. Journal of Public Economics, 193, 104345. https://doi.org/10.1016/j.jpubeco.2020.104345

Chotimah, S., Wijaya, T. T., Aprianti, E., Akbar, P., \& Bernard, M. (2020). Increasing primary school students reasoning ability on the topic of plane geometry by using hawgent dynamic mathematics software. Journal of Physics: Conference Series, 1657(1), 012009. https://doi.org/10.1088/1742-6596/1657/1/012009

Chotimah, Siti, Bernard, M., \& Wulandari, S. M. (2018). Contextual approach using VBA learning media to improve students' mathematical displacement and disposition ability. Journal of Physics: Conference Series, 948(1). https://doi.org/10.1088/1742-6596/948/1/012025 
Dong, C., Cao, S., \& Li, H. (2020). Young children's online learning during COVID-19 pandemic: Chinese parents' beliefs and attitudes. Children and Youth Services Review, 118(June), 105440. https://doi.org/10.1016/j.childyouth.2020.105440

Giannakos, M. N., Krogstie, J., \& Aalberg, T. (2016). Video-based learning ecosystem to support active learning : application to an introductory computer science course. Smart Learning Environments. https://doi.org/10.1186/s40561-016-0036-0

Guthrey, H. L. (2015). Victim healing and truth commissions: Transforming pain through voice in Solomon Islands and Timor-Leste. In Victim Healing and Truth Commissions: Transforming Pain Through Voice in Solomon Islands and Timor-Leste (Vol. 1522). https://doi.org/10.1007/978-3-319-12487-2

Putra, Z. H., Witri, G., \& Sari, I. K. (2020). Prospective elementary teachers' perspectives on online mathematics learning during coronavirus outbreak. Journal of Physics: Conference Series, 1655(1). https://doi.org/10.1088/1742-6596/1655/1/012057

Setyono, D. A., \& Cahyo, D. D. (2017). School services pattern in urban and rural areas: A comparatives study (Case study: Elementary school in Malang City and Malang Regency). IOP Conference Series: Earth and Environmental Science, 70(1). https://doi.org/10.1088/1755-1315/70/1/012051

Tambychik, T., \& Meerah, T. S. M. (2010). Students' difficulties in mathematics problem-solving: What do they say? Procedia - Social and Behavioral Sciences, 8(5), 142-151. https://doi.org/10.1016/j.sbspro.2010.12.020

Vicente, S., Sánchez, R., \& Verschaffel, L. (2020). Word problem solving approaches in mathematics textbooks: a comparison between Singapore and Spain. European Journal of Psychology of Education, 35(3), 567-587. https://doi.org/10.1007/s10212-019-00447-3

Wang, C. J. (2019). Facilitating the emotional intelligence development of students: Use of technological pedagogical content knowledge (TPACK). Journal of Hospitality, Leisure, Sport and Tourism Education, 25(May), 100198. https://doi.org/10.1016/j.jhlste.2019.100198

Weinberg, A., \& Thomas, M. (2018). Student learning and sense-making from video lectures. International Journal of Mathematical Education in Science and Technology, 49(6), 922-943. https://doi.org/10.1080/0020739X.2018.1426794

Wijaya, T. T. (2021). How chinese students learn mathematics during the coronavirus pandemic. International Journal of Educational Research and Innovation (IJERI), 15, 1-16. https://doi.org/https://doi.org/10.46661/ijeri.4950 
Improve The Logical Reasoning Ability of Primary School Students by Using Video Learning Assistant Teaching, Zhouli Huang, Ying Zhou, Tommy Tanu Wijaya, Ke Yan

Wijaya, T. T., Hidayat, W., \& Zhou, Y. (2020). Development of Interactive Learning Video on Linear Program. Universal Journal of Educational Research, 8(12A), 7530-7538. https://doi.org/10.13189/ujer.2020.082537

Wijaya, T. T., Li, L., Hermita, N., Putra, Z. H., \& Alim, J. A. (2021). Helping Junior High School Student to Learn Fibonacci Sequence with Video-Based Learning. International Journal of $\begin{array}{llll}\text { Interactive } \quad \text { Mobile } \quad \text { Technologies } & \text { (IJIM), } & \text { 15(11), }\end{array}$ https://doi.org/https://doi.org/10.3991/ijim.v15i11.23097

Wijaya, T. T., Ying, Z., \& Suan, L. (2020). Gender and Self-regulated Learning During COVID-19 Pandemic in Indonesia. Jurnal Basicedu, 4(3), 725-732. https://doi.org/10.31004/basicedu.v4i3.422 